\title{
HeNRIK LARSEN
}

\section{5 \\ Discourse analysis in the study of European foreign policy}

Social constructivist discourse analysis has, since the early 1990s, become increasingly popular across the social sciences, including international relations. The aim of this chapter is to outline the possibilities for the use of discourse analysis in the study of European foreign policy. Pure rationalists often dismiss EU foreign policy as 'just words' or 'declaratory diplomacy' as it is often labelled contemptuously: 'Even in this area [the Middle East] ..., although EC policies were fairly well coordinated, they were primarily declaratory and had little actual effect' (Gordon 1997: 84). According to this view, what really matters in an analysis of the effects of EU foreign policy is implicitly or explicitly seen to be the effects of clearly identifiable non-discursive practices. In general terms, the argument in this chapter is that the study of EU foreign policy lends itself well to an analysis of discourse. Because a discourse approach sees language as a material part of social reality it can analyse aspects that, in particular, rationalists, downplay. Language is seen as a rich source of analysis rather than 'just' words. Struggles over social meaning as they are played out in declaratory diplomacy are seen as just as central to international relations as they are to other domains of social life. Something happens when social meaning is produced in texts and talk. Discourse analysis is a theory and a method for analysing this. This does not, of course, rule out the study of power or of 'policy effects'.

Neither does it necessarily lead to a neglect of the study of other than discursive practices (if such a distinction is relevant). But it means that language is seen as having an important independent status. It is not just a mirror of other social practices or a smokescreen covering up what is 'really happening.' The focus in this chapter is on the research potential of discourse analysis rather than on a comparison of discourse analysis with all other possible approaches to analysing European foreign policy. The main point is that there is ample scope for the use of discourse analysis in the study of European foreign policy, and that much work remains to be carried out drawing more directly on the insights of discourse analysis. 
The empirical focus of this chapter is EU foreign policy. EU foreign policy is understood as the foreign policy of the EU as a whole (i.e. as a 'negotiated order'; Smith, 1996a). In certain places I do, however, distinguish between the pillars when this is relevant in the context. I do not directly address the issue of the analysis of the national foreign policies of European states, although this is clearly also a way of understanding 'European foreign policy' and applying discourse analysis (for this see for example Larsen 1997b). However, the link between national and European foreign policies from a discourse perspective is briefly addressed.

In the first part of the chapter, I briefly introduce the main features and assumptions of discourse analysis within the general field of social constructivism, and present the main implications of discourse analysis for concrete empirical research. I end by describing the main dimensions of discourse analysis using the categories of Milliken (1999): representation, policy practice and play of practice. In the second part of the chapter I highlight the use, and potential use, of discourse analysis in relation to four different aspects of EU foreign policy: is the EU constructed as an actor; as what kind of actor; what kind of values does it draw on; and how are EU foreign policy decision-making procedures constructed? I refer to research that has already been conducted, including research that does not explicitly draw on a discourse framework but which lends itself to a discourse analytic interpretation of the results. The last section includes the concluding remarks.

\section{Discourse analysis and social constructivism}

In the following, I introduce the main assumptions of discourse analysis, locating it within the wider field of social constructivism, and I present the implications for concrete analysis. The section argues for the use of discourse analysis as a research methodology based on the assumption that language constitutes meaning.

\section{Social constructivism}

The self-understanding of social constructivists within the academic discipline of international relations is that it is a position that can clearly be distinguished from discourse analysis and post-structuralist approaches (see for example Adler 1997b: 320-332; Jeppeson, Wendt and Katzenstein 1996: 46). ${ }^{1}$ However, contrary to this but in line with the tendency in many other disciplines, I see discourse analysis as a particular theoretical and methodological position within the general perspective of social constructivism ${ }^{2}$ and not a fundamentally different position. I will therefore outline what I see as the main features of social constructivism, and subsequently go into discourse analysis in more depth.

A central point in social constructivism as it is broadly used across disciplines is that the social world is only accessible to us via our ways of categorising it. Our knowledge about the social world is not a mirror image of the world, 
but a product of our ways of categorising it. The general point of departure is thus anti-essentialist, although social constructivist approaches vary widely with respect to whether they include essentialist elements. Human knowledge is seen as historically and culturally specific, which means that it is basically contingent: it could be different under other historical or cultural circumstances and could give rise to other identities and social relations. Moreover, the construction of intersubjective views has concrete social consequences: different views on the social world lead to different social actions and different forms of social organisation (Burr 1995: 2; Jørgensen and Phillips 2002: 13-14). Whether this is to be understood in terms of constitutive effects, causal effects (see for example Wendt 1999) or social phenomena of a different and more complex nature (see for example Alker 1999: 148; Smith 2000a: 156-60) is a question on which views diverge. Of special relevance for the study of politics, a general point in constructivism is that interests and derived policies are shaped within a particular framework of meaning and are not exogenously given. Actors do not have preferences and interests that are external to their understanding of the social world and their own identity and place therein (see for example Weldes 1996).

However, constructivist approaches differ over how this central meaning dimension of social life is to be conceptualised and analysed. The approach taken depends, to a large extent, on whether language is seen as a transparent conveyor of meaning or not. If language is seen as a neutral conveyor of meaning (as is mostly the case in phenomenology and symbolic interactionism), this naturally leads to little interest in the systematic study of linguistic practices and the language in texts.

\section{Discourse analysis}

Social constructivist approaches drawing on discourse analysis, in contrast, take as their point of departure that we need to focus on the language used in social life as a central and independent object of study. The background for that is the view that there is no meaning residing outside language or that, even if there is meaning outside language, there is no way of studying the meaning 'behind' language. No investigation can therefore take place directly at the level of ideas. We are always, strictly speaking, studying the dynamics of language.

The discourse approach to language questions the idea of an abstract and general structure of language as assumed by the founder of linguistic structuralism, Saussure. As soon as we enter into the substance of social language, we do not find one general system of meaning, but rather special systems of meaning whereby meanings of words differ from system to system, that is from discourse to discourse. Expressed in theoretical terms close to Foucault (1989 [1972]; cf. Norris 1982), the impact of words derives not only from the differences between them, as Saussure argued, but also from the social values given to them (or more correctly to the social values given to the different signifiers). Language is, therefore, more fluid and flexible. 
It is important to note that definitions and usages of the term 'discourse' differ considerably from one approach to the other. In traditional linguistics and social psychology, discourse is often used as a micro concept, for example as a way of analysing the pattern of everyday conversations among individuals in different situations (families, jobs, and so on). Contrastingly, discourse is widely used in social research (including interdisciplinary approaches in linguistics and social psychology) as a macro concept to analyse how language both constrains and constructs social processes; that is, how language constrains the choices of agents and how it more fundamentally generates agents and social processes. This latter usage is particularly associated with Foucault. Here I only deal with social constructivist approaches to discourse analysis. The focus here is therefore on the second kind of approach (discourse as a macro concept).

Along the lines of Foucault (1989 [1972]), I understand discourse as a limited range of possible statements promoting a limited range of meanings. When I employ the term 'discourse analysis' in the following to discuss its use in European foreign policy, I take as the point of departure macro approaches which fall into the categories of discourse theory (Laclau and Mouffe) and critical discourse analysis (as for example represented by Fairclough) (see below). Within these macro approaches a central distinction is between text-oriented approaches that engage in detailed analysis of individual texts to show how the meanings of broader discourses are promoted, and approaches which do not engage in detailed textual analysis but focus on broadly based discourses which are identified in relevant texts. Critical discourse analysis (CDA) belongs to the first group whereas the discourse theory of Laclau and Mouffe belongs to the second. ${ }^{3}$

\section{Discourse analysis versus other social constructivist approaches}

How, in general terms, is a discourse approach distinct from social constructivist approaches which assume that language is transparent? There are four main implications for concrete studies as compared with studies which see language as transparent.

First, the strong social and transsubjective character of the beliefs identified is stressed via the focus on language as the concrete social medium. Discourses are not seen as the product of individual language users' brains or psychology. Rather, individual views and identities are constructed by discourses which are formed and changed in social interaction and thus are fundamentally social. An analytical focus on the views of an individual or a politician is therefore only relevant as expressions of broader societally shared discourses (contrast this with, for example, Wendt's tendency to focus on Gorbachev in Wendt 1992: 420-24).

Second, since language constitutes meaning, the analytical focus is not on what is 'really' meant by a particular text or statement. What is really meant is not something the researcher can know since we do not have access to meaning outside language. We therefore stay at the 'surface' of the text and pay attention to the narrative structures and vocabulary in the text. Tactical/rhetorical use of language is certainly seen as important within discourse analysis. It is, however, 
seen as constrained by the discourses in which the strategic actors are embedded. This is in contrast to those social constructivist approaches which consider language as transparent and which are often drawn towards inquiring about what is 'really' meant by a text because there is no concept of what the level for studying meaning is (how 'deep' we need to go). This can lead to a neglect of the transsubjective, constraining and productive character of texts and to a focus on individual and social meaning as something outside the text. Discourse analysis, in contrast, has a relatively clear view of how and where meaning is to be studied - at the level of the language.

Third, discourse approaches see language as inherently unstable, fickle and fluid as meanings are permanently being defined and redefined as an integral part of the social process. They are not a permanent property of individuals or groups. This does not mean that elements of stability may not be identified. A central goal is indeed to show how meanings are temporarily fixed in discourses, and where there are dominant discourses where one would not a priori expect them. There might be both an interest in continuity and change (see for example Larsen 1997b; Wæver 1998). Simplifying maybe more than is fair, non-discourse approaches tend to focus more on stability, but when they do identify change it is often seen as a total change.

Fourth, instead of the focus on what is 'really' meant in a particular text, the focus is on the discursive structures cutting across texts, or the way discourses dominate or compete in particular texts. The question asked is how the individual text is an articulation of broader discursive structures rather than the concrete message or argument in the text. One is interested in narrative structures and vocabulary in the language used.

\section{Implications for empirical research}

It is important to stress that social constructivist discourse analysis is a theory (and a method flowing from that) about the shaping of the social world through the process whereby meanings are produced and reproduced. It contends that the social is, at least to a large extent, constructed in language. But as a theory, it does not say anything about the substance or content of the construction. The ontology is empty. It says that the social world is constructed, not what kind of social world is constructed. What we can say is that the language used plays a central part in constructing social life (and is not a derived phenomenon) and that language therefore is a central object of study. But discourse theory itself cannot say anything about what kind of discourses are present and fix meaning in particular contexts. This is an empirical question. We have to formulate our questions about a particular area from our knowledge of the field (interpreting them, of course, within the terms of discourse analysis sketched out above).

Milliken (1999) has attempted to formulate the central elements of research from a discourse analysis perspective within international relations, arguing that there is by now something that amounts to a discourse analysis research programme. Good scholarship in this area, she argues, is built upon a set of 
theoretical commitments that organise discourse studies and restrict appropriate contexts of justification and discovery. Among the most important commitments of this research programme are three 'analytically distinguishable bundles of theoretical claims' (Milliken 1999: 228, 231). These three key claims are:

1 Discourses are systems of representation (the general constructivist understanding of meaning). Discursive studies must empirically analyse how discourse constitutes the world in meaning.

2 Discourse produces subjects and objects defined by the discourse. Discourses make intelligible some ways of acting towards the world and exclude other possible modes of identity and action. The analytical focus should be on how discourse produces this world, including its policies.

3 Discourses are changeable and historically contingent. Discourse analysis should analyse the indeterminate play of practice between discourses and how efforts are made to stabilise and maintain dominant meanings. This also leads to analytical attention being paid to whether there are alternative discourses which are silenced by the hegemonic discourse or whether there are open discursive antagonisms (Doty 1997: 375-9; Milliken 1999: 229-31). ${ }^{5}$

Discursive dynamics and struggles are central in social change. I return to these categories below when I look more closely at the use of discourse analysis in the study of European foreign policy.

\section{Discourse analysis and European foreign policy}

A central question in the literature and political debate about European foreign policy is the issue of whether one can talk about a common understanding of EU international actorness in or outside the EU. This question can be said to lie behind many other issues of EU foreign policy. Is there a common understanding of EU actorness at the EU level which shapes general policy? Or is there, rather, a battle over the content of European actorness in relation to every single policy issue which means that we are really closer to the realists' conception of EU foreign policy as the lowest common denominator of the national views or national cost/benefit considerations? (See for example Gordon 1997; Bretherton and Vogler 1999). The representation of EU actorness is a central issue to approach from a discourse perspective. If there is no joint representation of the EU as a foreign policy actor of some kind at the EU level among the central EU actors or outside the EU, it may not make sense to inquire further into the issue of the foreign policy of the EU from a discourse perspective focusing on the EU level (whereas it might be interesting to inquire into the discursive dimension of various national European foreign policies and how these make sense of and shape European foreign policy; see for example Larsen 1997b). In this case the basic realist approach to EU foreign policy would seem to be confirmed as the policy stances taken by the EU vis-à-vis the outside world are a function of 
nationally generated views. ${ }^{6}$ However, if the EU is found empirically to be constructed as an actor, the next general analytical step from a discourse perspective is to ask what kind of actor is constructed, including what kind of values are articulated as an inherent component of actorness. Also part of this general focus of analysis, although at a lower level of abstraction, is the issue of how the actors involved construct and reproduce the decision-making procedures linked to this international actor. Rationalists including neo-functionalists assume these to take a particular character given the nature of the actors involved (states and institutional actors). For discourse analysis, it is an empirical question how these actors construct their mutual relations in language. Key questions in relation to EU foreign policy from a discourse perspective, then, include the following: (1) Is the EU constructed as an international actor? (2) If it is, what kind of actor is constructed? (3) What kind of values is this actor based on? (4) How are its decision-making procedures constructed by the actors involved?

In the following, I will suggest preliminary avenues of inquiry into these issues of European foreign policy, partly drawing on the work that has been done in these areas, including my own work (Larsen 2000a, b). ${ }^{7}$ The aim is to suggest avenues for future research from a discourse perspective, rather than attempting a comprehensive presentation of these issues. In presenting these issues, I have structured the presentation along the three dimensions of discourse research suggested by Milliken (1999) outlined above, although I do not deal with them in the same order (I merge the first and the third dimensions). I then discuss the four substantive issues identified in relation to EU foreign policy along the dimensions of representation and play of discursive practice and then social practice (policy). It is important to stress that the distinctions between the three dimensions are analytical rather than ontological. In general terms, it is part of a constructivist understanding that all social practice is meaning-based. Policy (part of the social practice) is therefore always constructed in meaning through a system of representation. An analytical distinction between representation and policy does not therefore imply that policy is of a different ontological order.

The analytical distinction is relevant, however, because the relationship between representation and policy is not simple (Larsen 1997; Hansen 1998: 87-97; cf. Wæver 1998). ${ }^{8}$ Even if policy is understood solely as an articulation of discourse, ${ }^{9}$ the challenging question is what discourse(s) are articulated within this particular field, including in the process of implementation (Milliken 1999: 240). Moreover, I am only concerned with indicating the possible extent of this discursive shaping of policy practices, not in a comparison with possible effects of other practices of a different ontological order, let alone attempting to combine different approaches. Discursive representations are assumed to constitute an enabling framework for certain policies and to exclude other policies. The focus in the play of discursive practice is the discursive struggle which is played out between competing discourses. To a large extent the discursive struggles in relation to the shaping of EU foreign policy can be seen as struggles between 
states $^{10}$ and instititutional actors adhering to different discourses. The interesting analytical question in this context is which and whose discourses, if any, become hegemonic or dominant in EU foreign policy. Power (which can be understood as both constitutive of actors and as constraining actors) and dominance of particular discourses are in a Foucauldian perspective two sides of the same coin. Finally, for reasons of space, I do not cover all the aspects which discourse analysis can be used to illuminate (as suggested by Milliken). ${ }^{11}$

\section{The EU as an international actor}

\section{REPRESENTATION AND PLAY OF DISCURSIVE PRACTICE}

As mentioned above, representations of actorness are central for the study of the $\mathrm{EU}$, since they can be said to constitute the point of departure for further inquiry into EU foreign policy from a discourse perspective. Across EU documents a discourse can be identified according to which the Union is constructed as a unit which defends its own interests and has an obligation to take on responsibilities in the light of international challenges (Larsen 2000a). Expressions such as the following from Article 2 and Section V on the CFSP in the Amsterdam Treaty are common in EU documents: 'The Union shall [...] assert its identity on the international stage' and, 'To safeguard the common values, fundamental interests, independence and integrity of the Union' and 'The Union shall define a CFSP' (in the TEU it was 'The Union and its Member States'). They are statements belonging to a common discourse on EU international actorness.

Within rationalist approaches, EU actorness is mainly treated as a question of what they see as the non-discursive impact on the world (see for example Gordon 1997: 84). Clear policy effects are the key to establishing whether the EU has actor status, often based on the identification of some hard capabilities. A discourse approach starts from a different analytical position. According to this perspective, the Union is an international actor if it constructs itself as one visà-vis the rest of the world and if other international actors conceive of it as such. The crucial point therefore is that there is a dominant EU discourse which articulates the EU as an international actor. To a large extent other international actors also conceive of it as such (Bretherton and Vogler 1999).

That the Union constructs itself as an international actor does not, however, mean that it does not also construct itself as belonging to other international entities. For example, the EU clearly constructs itself as a part of the West. But it does not equate itself completely with the 'West'. It is a separate political actor which promotes Western values (Larsen 2000a).

In Union documents (in the Council context) there is, surprisingly, a hegemonic, unitary discourse on the assertion that the $\mathrm{EU}$ is an international actor with its own interests and policies. This is the discourse which shapes the EU's policy practice (see below). The discourse that contests this point is a discourse according to which the Union cannot be an actor because there are seen to be no 'real' European interests. According to this discourse, if the Union has actor 
features it is because it has taken on powers which rightly belong elsewhere, mostly to the states (as right-wing adherents to this discourse would mostly claim) or to more broadly based international and democratic organisations (as some on the left and some Greens would argue). It is presented as on its way to becoming a superstate. The language within this discourse is therefore one of misuse of power rather than just power (strong sceptics usually want the Union to be less of an actor and more of a loose forum for coordination). This discourse, however, is, unsurprisingly, not present in official EU documents and does not shape EU policy practice. Rather, it is part of the discursive battle at the national levels and, to a much lesser extent, in the European Parliament, about the future construction of the EU as a whole vis-à-vis the member states. At the national levels, this discourse has a strong position in Britain and in Denmark (Larsen 1999) but can also be identified among the so-called souveraintistes in France.

\section{POLICY PRACTICE}

The dominant discourse on the Union as an international actor with its proper interests is reflected in the Union having a policy line across a whole range of functional and geographical areas, although of varying intensity and detail. Union policy is clearly most uniform in relation to trade, fisheries and agriculture. In terms of geographical scope, Union policy is most intensive and detailed with respect to the areas around Europe, the Central and Eastern European countries (CEEC) in particular. In these policy areas, the Union's policy practices can be said to have contributed to shaping international policy processes. This is particularly clear if the scope of the inquiry is not just taken to be the CFSP but Union policy as a whole. The exceptions to this so far have been strategic and military affairs in the sphere of high politics and crises management (with the possible exception of Cyprus), although this might be changing (see below). Moreover, the Union is considered as a significant actor by important sections of the international community in many policy areas (Bretherton and Vogler 1999). Whether there is seen to be a gap between the expectations (internal and external) for the Union's ability to act and the Union's impact on international political processes (Hill 1993a, 1998) is to a large extent a question of what is the base of comparison or what stories/expectations are used to evaluate the actions of the Union (Jørgensen 1998). In some cases, the EU can be said to have more policy instruments than states or other organisations (K. Smith 1998a), in other cases fewer. What is clear is that the discursive practice constructing the Union as an international actor is also a series of political practices across different policy fields.

\section{What kind of international actor?}

REPRESENTATION AND PLAY OF DISCURSIVE PRACTICE

In the dominant discourse, the Union is presented as a unique and complex construction; it is not presented as taking the place of the member states but is an 
inseparable counterpart to the member states (Reflection Group 1995: I-III). In this light, the frequent use of the term 'identity' or 'genuine identity' in Union discourse in relation to the need to strengthen the EU in the international context is significant. The Union is articulated as an international actor, but not as a state or a future state (Larsen 2000a; cf. Wæver 1995, 1996). Along the same lines, Wæver (1995) has labelled the understandings of the Union 'post-sovereign'.

An important issue in the literature in relation to EU actorness is the issue of whether the EU is a civilian power (Duchêne 1972, 1973; Hill 1990). The debate about whether the EU is and should remain a civilian power was launched by Duchêne's work in the early 1970s which argued that there were international and internal factors that pulled the EC towards remaining a civilian power and that it was in the EC's interest to remain one (Dûchene 1972, 1973). From the perspective of this chapter, the question of whether the EU is by its nature a civilian power can be recast in discourse terms: it would not be seen as a question of what the Union in essentialist terms $i s,{ }^{12}$ but rather what kind of actor is constructed in the discourses articulating the Union's actorness. This approach, on the one hand, means that the nature of the Union is not given once and for all since discourses are never stable. On the other hand, it also means that access to particular means - military means of course being the most interesting in this context - does not per se make the Union into a particular kind of actor. Rather, the decisive element is how these means are articulated as part of Union actions. After the entry into force of the TEU in 1993, the Union formally gained access to military means through the WEU, at least on a very small scale. And yet the dominant discourse within the Union did not articulate the Union as a military power in relation to concrete international issues until the second part of 1998 (see below). Until 1998, the dominant EU discourse was one which stressed the role of civilian means in the foreign policy of the Union in relation to solving concrete international issues (Larsen 2000a). In the original formulations of the concept of civil power (Duchêne 1973; Hill 1990), the emphasis on persuasion remained an important part of the concept. While persuasion remains an important element in the way the Union conceptualises its political actions, there is little doubt that the Union in the 1990s has constructed itself as a political power which should draw on its political, economic and military means to further its political goals (Larsen 2000a: 224).

While the dominant discourse in Union documents until the late 1990s, then, has been a discourse which has stressed the civilian power character of the Union in relation to concrete issues in international relations, including conflict resolution, the presence of another discourse can also be identified in Union documents. According to this discourse, access to military means is central to asserting the international identity of the international (diplomatic) standing of the Union as an actor. This discourse coexisted with the civilian power discourse in the 1990s in official Union documents (Larsen 2000a), although the civilian power discourse dominated policy practice until 1998. The division between these two discourses could also be found in relation to the treaty changes in the 1990s. 
But from 1998, the hitherto dominant civilian power discourse mentioned above has been challenged by another discourse which has since been gaining dominance in Union documents. Within this discourse, the civilian power discourse elements have been articulated with the element that the Union's access to military means might be beneficial in responding to international crises and in contributing to international peace and stability, so that the Union has access to the full scope of instruments. This new dominant discourse could be called the 'full instrumental power discourse'. The element that the Union's use of military means may be beneficial in responding to international crises and in contributing to international peace and stability is now articulated as part of the dominant discourse:

[The Council] should have the ability to take decisions on the ... Petersberg Tasks ... To this end, the Union must have the capacity for autonomous action, backed by needs to develop a capacity for autonomous action backed by credible military forces ... in order to respond to international crises without prejudice to actions by NATO. The EU will thereby increase its ability to contribute to international peace and security in accordance with the principles of the UN Charter. (Declaration by the European Council in Cologne, 3 June 1999, on strengthening the common European policy on security and defence $)^{13}$

From a discourse perspective, the articulation of the EU as an actor that may also draw on military means for instrumental purposes within the 'full instrumental power' discourse might be seen as a change in the nature of the EU as an international actor. The discourse which stresses access to military means as central to asserting the Union's status and identity can, however, still be identified in EU documents. So while a new dominant discourse articulates civilian and military elements as part of an instrumental whole, elements of a more identity- based discourse continue to exist (e.g., the Conclusions from the European Council in Cologne, 3-4 June 1999 read: 'The members of the European Council are convinced that the EU shall play its full role on the international stage'). Meanings at the EU level concerning the nature of EU actorness can therefore not be said to be fixed.

\section{POLICY PRACTICE}

The policy activities of the EU have so far concentrated on the civilian aspects of foreign policy (stability pacts, trade and cooperation agreements, political conditionality, declaratory diplomacy, etc.) and excluded military instruments (apart from the joint action according to TEU J.4.2 in 1998 consisting in training mine clearers) in line with the dominant civilian power discourse. It might be argued that this is because the Union has lacked the means to conduct such operations. In the 1990s, however, the Union did in principle have access to military means, although small scale, through the WEU, but only drew on them to a negligible extent. It can be argued, then, that the 'civilian power' discursive practice shaped the use of policies and policy instruments used (see below). The 
articulation of the new military elements into the dominant discourse from 1998 has enabled a new momentum for the Union in the field of defence and the shaping of the new institutional structures in the Union which will increase the Union's ability to use military means and the likehood of it using them. It is within this framework of meaning that it has been decided that the EU should have access to military forces earmarked for this purpose by 2003 at the latest.

\section{The EU's values}

REPRESENTATION AND PLAY OF DISCURSIVE PRACTICE

Across EU documents the Union's (foreign policy) identity is articulated with liberal values, as in the following example: 'The Union is founded on the principles of liberty, democracy, respect for human rights and fundamental freedoms, and the rule of law, principles which are common to all member states' (TOA Article 6).

These are presented as the values that the Union is meant to defend internationally ${ }^{14}$ and international conflict resolution is linked to furthering these values. These liberal values are linked in chains of equivalence. (Within the framework of Laclau and Mouffe (1985) a chain of equivalence is a linking of concepts whereby the difference between concepts disappears). Within discourses, elements are interconnected and mutually supportive, so that one concept is presented as leading logically to the other (Laclau and Mouffe 1985: 127-34) which contribute to constructing the identity of the Union: 'The European Council recalls the contribution of human rights to the establishment of conditions which are more conducive to peace, security, democracy and social and economic development' (European Council, Presidency Conclusions, 1997). There can thus be said to be an EU discourse on joint values, and not just on decision-making procedures, as is sometimes suggested (see for example Forster and Wallace 1996).

Discourse approaches consider identities as relational rather than as given attributes of actors. They therefore focus on how identities are constituted as a mirror of an 'other' or a threat. ${ }^{15}$ An important focus in relation to EU foreign policy is therefore who is constructed as Europe's other and hence contributes to constituting the liberal values as central in the dominant discourse of the Union. Campbell (1992), more generally, sees the articulation of threats as an essential part of establishing a foreign policy identity. Articulation of threats is also an important part of creating the inside-outside distinction between the domestic and the international which is arguably necessary for the establishment of a foreign policy identity (Walker 1990, 1993; L. Hansen 1995: 118-19). In establishing who is constructed as threats to Europe as an 'other', the 'securitization' approach is central from a discourse perspective. The core of this approach is to analyse the language used in a particular context to establish what is constructed as an existential threat in relation to a particular referent (e.g. a country or an organisation) - that is, the focus is on the use of a grammar of 
security. The grammar of security allows the actors to break the normal rules of the game (Wæver 1996; Buzan, Wæver and de Wilde 1997). Along the lines of Campbell (1992), the identification of a concept of security in the EU discourse is also interesting because the articulation of threats, an 'other', is a crucial part of establishing a foreign policy identity. The question then is, what elements are constructed as threats to European or EU security?

Wæver (1996: 122) argues that the threat to European security is not found in space but rather in time: Europe's past of wars, genocide and dictatorship. The threat to European security, he argues, is constructed as threats to European integration. Within the dominant discourse, EU integration is therefore articulated as security (Wæver 1996). One could argue, then, that what is 'othered' is Europe's past so that the emphasis on the liberal values in the Union can be seen as a negation of Europe's dark past (Larsen 2000a; cf. Wæver 1996: 122).

Conversely, Neumann (1998) argues that Europe's 'other' (if not a direct threat) is to be found in space in the form of Russia or the 'East'. Russia or the East, Neumann argues, has historically and up until today constituted a defining pole for what Europe is not - that is, barbaric, authoritarian and Asiatic. Although Russia has at times been presented as becoming more European, it has always been discursively constructed as in between Europe and Asia, or on its way to Europe. The main metaphor used in the discourse has been one of transition. This is arguably also the case today (Neumann 1998: 111-12, 160, 207). ${ }^{16}$ Along the same lines, the Central and Eastern European countries' non-Easternness becomes defining for the EU's enlargement policy and hence for EU foreign policy directed against this region.

On the basis of an analysis of EU documents in the 1990s (Larsen 2000a), I have argued elsewhere that the values constructed as part of European (foreign policy) identity can be seen as constituted with reference to internal as well as external dangers to European security. The internal dangers are seen as a cessation of EU integration and a failure to complete enlargement, which are closely linked. They can be seen as constituted by a negation of an 'other' in the past as argued above, and thus constitutive of the liberal values. The external dangers are presented as instability in Russia (unstable democracy), the Mediterranean area (unstable democracy and Islamic fundamentalism) and non-geographical dangers (environmental risks, crime, etc.). These dangers can also be seen as constitutive of the liberal values at the core of the EU's foreign policy identity. The complex multitude of dangers and risks in EU discourse does not lead to a clear-cut binary othering in relation to European security (Wæver 1996: 122). But it reinforces the liberal values at the core of European identity, since it is the negation of these values which is part of the construction of dangers (Larsen 2000a).

No challenge has been mounted to the discursive construction of the core values of the Union as a foreign policy actor - these are universally accepted to be liberal values. There do not seem to be other general discourses in EU documents which draw on something different from a liberal chain of equivalence. Rather, disagreements about the shaping of policies can be found within this discourse. ${ }^{17}$ 


\section{POLICY PRACTICE}

What kind of policy practices are enabled by the dominant discourse on the liberal values? An important aspect of the Union's policies consists in pronouncing itself on human rights globally, and not least in Africa (e.g. in relation to the situations in Niger, Nigeria and around the Great Lakes). ${ }^{18}$ Political conditionality, which in the 1990s has been an integral part of the Union's policy towards demandeur countries, consists in linking improvements in conditions in the liberal values of the countries in question to economic support or conclusion of trade agreements, positively or negatively (K. Smith 1998b). The main part of the Lomé agreements also contained clauses on human rights from 1989. Political conditionality in some form can be seen as an element in the Union's policies globally from the Central and Eastern European countries to Africa. However, the way it is applied varies considerably. Countries that are important to the Union for commercial or political purposes generally suffer less from negative sanctions and there are often disagreements about what policies to adopt within the general liberal discourse, (K. Smith 1998b: 274). But the liberal discourse identified contributes to the EU's policy articulations in many fields. The question is, with what kind of other discourses is the liberal discourse co-articulated?

Policy practices relating to management of conflicts and furthering regional stability can be seen as based on the central role of the liberal values (Larsen 2000b). The Stability Pacts for Central and Eastern Europe and for the Balkans can be seen as policy elements shaped within the discourse whereby the liberal values play a central role in conflict resolution.

In a broader sense, the ways in which other regions around Europe can be seen as contributing to constituting EU identity in EU discourse through 'othering' is manifested in EU policies towards these regions. The significant issue is whether the policies take the form of integration with 'us', aiming at membership, or whether the policies are rather an expression of 'othering' and are not leading up to membership. The policies towards the CEEC can be said to be inclusionary to such an extent that it is debatable whether it can still be said to be foreign policy, based as it mostly is on Pillar One instruments and extensive cooperation about 'domestic' issues (M. Smith 1996b). The policies towards the Mediterranean and Russia, although highly institutionalised (Barcelona Declaration, joint strategy/ partnership agreement with Russia), are arguably about managing relations with someone outside (with the aim of preventing instability), not with bringing prospective insiders or members closer to the EU (Larsen 2000a).

\section{EU decision-making}

REPRESENTATION AND PLAY OF DISCURSIVE PRACTICE

Discourse analysis asks whether there is a common procedural (decisionmaking) discourse which cuts across actors and institutions which might mean that intergovernmentalism (in the case of the CFSP) is not the defining feature of $\mathrm{EU}$ foreign policy decision-making. This is a different avenue of research from 
approaches which study the European foreign policy decision-making process based on the formal structures (intergovernmentality for the CFSP) or the character of the participating actors (primarily states but also supranational actors).

A significant amount of empirical and theoretical work on the CFSP has been published which includes considerations about common procedural understandings (less has been done on the external relations of the EU) and even aspects of language which cut across state actors (Jørgensen 1996, 1997a; Tonra 1996, 1997, 1998, 2001; Ekengren 1997). Although the method and the analytical frameworks used are not discourse analytical, many of the findings lend themselves to an interpretation drawing on discourse analysis. For example, the 'consultation reflex', and the identification of a pull towards the median in relation to forming common positions (as identified by Nuttall 1992: 312, 314), can be seen as part of a CFSP discourse. This discourse can be identified in the numerous reports on the EPC/CFSP since 1970.

The understandings identified by Tonra $(1996,1997,1998,2001)$ in particular can be understood as discursive representations of CFSP procedures present in the EU institutions and member states. Tonra stresses, for example, that socialisation has led to a primary coordination reflex with the EU partners for new policy initiatives. The language used in the CFSP has increasingly become a language shared by all partners (Tonra 1997: 187) and the national foreign policy-making process is increasingly driven by the EPC or European agenda. European political cooperation has become the central forum for the delineation of foreign policy interests in each of the three states he examined (Tonra 1997: 190). There is a procedural EU discourse of consultation and cooperation which shapes the decision-making process. 'Side payments' or 'trade-offs' are not the order of the day when formulating CFSP stances. Rather, policy-makers understand themselves as being engaged in a process of collective policy-making which contributes to formation of their foreign policy identity (Tonra 1997: 186-7; Tonra 1998: 11-12).

It is interesting to compare a discourse approach to the issue of common procedural understandings with a more phenomenological/symbolic interactionist approach, since the latter approaches are often implicitly drawn on in analyses of the CFSP. A phenomenological approach will tend to see the development of these CFSP norms as a result of interactions between individuals involved, particularly the political directors. The informal, clubby atmosphere of this group is a key object of study, and biographical and personal evidence are treated as important sources. Distinctions such as the effects of socialisation versus what individuals willingly concede to and which might therefore involve an understanding of a rational calculus are drawn on (see for example Glarbo 1999). Social 'learning' is seen as central for identity formation (Checkel, 1998: 344).

A discourse approach, in contrast, will tend to see the understandings developed as results of socially shared discourses produced and transformed through social interaction. The informal clubby atmosphere, which has characterised the EPC and to a lesser extent the CFSP and which is often credited with 
being the hot-bed for developing common understandings, is seen as an expression of a particular CFSP discourse - perhaps a hybrid of traditional diplomatic discourse and community discourse; it is not the result of individuals' isolated views, but of socially shared discourses that individuals draw on as strategic resources in text and talk in the CFSP. A discourse approach would focus more on patterns and constraints than phenomenology. These patterns and constraints would be understood in terms of discourses which construct objects and subjects in particular ways and thus shape and constrain action. A discourse approach would, for example, note how the consultation reflex language was present already from 1973, and study how the EPC/CFSP developed within this discursive framework. Support for this approach is provided by the fact that, although individual civil servants get to know each other in the EPC/CFSP working groups and in the political committee, in diplomacy individuals are generally very mobile, continually being replaced. There is not the personal continuity which would provide for a person-based 'communaute de vue'.

There is a conflict between a hegemonic discourse which assumes a supplementary European forum for foreign affairs and another discourse which argues that such a decision-making forum is an aberation, and breaks with the national model of foreign policy-making which is seen as the natural one (as outlined under 'international actor' above). Most adherents to the latter are to be found on the political wings, and not within the political/administrative elite (with the UK as a possible exception). This discourse is predominantly articulated within some EU member states, Britain and Denmark in particular (Larsen 1999), and not at the EU level.

In a broader perspective, the key questions are whether one can talk about a discursively constructed European (political) identity, and among which actors - states and institutions - such a discourse might be dominant. The questions relate the issue of meanings in European foreign policy procedures with the framework of meaning of the rest of the European polity. Fundamentally, this is linked to the issue of whether there is a European demos or a European public sphere and how this might affect EU foreign policy (Guénno 1998, 2000; Hix 1998; Peterson 1998: 3). Here is an issue where much more research from a discourse perspective is needed, research which cannot, of course, be limited to EU foreign policy.

\section{POLICY PRACTICE}

The discourse on intensive cooperation in foreign affairs in relation to the CFSP outlined above produces and reproduces political practices in EU foreign policy: there has been a Europeanisation and a Brusselisation of national foreign policy-making, although this does not necessarily manifest itself in the same way in all EU member states (Whitman 2000b). A recent study of the foreign policy of EU member states concludes that it now seems more appropriate to suggest that EU Member States conduct all but the most limited foreign policy objectives inside an EU context' (Whitman 2000a: 271). Most departments in 
member states' foreign ministries are now in some ways involved in EU foreign policy-making (Spence 1999: 262), and national political/administrative decision-making is to a large extent adapted to the calendar of EU decision-making (for an example see Ekengren 1997). At the EU level, the fact that many EU policy positions arrived at can be seen as the median of the many national stances rather than the lowest common denominator (Nuttall 1992: 314) can be seen as a policy practice produced by the discourse which cuts across the actors in EU foreign policy-making and ascribes a special status to EU foreign policy coordination.

The policy practice of the CFSP cooperation discourse can also be said to consist in the way it produces and reproduces the role of legitimate actors in EU foreign policy decision-making (member states' diplomatic and other representatives, the High Representative of the CFSP, the Commission). The European Parliament, for example, is not taken very seriously as a political actor by the Council, contrary to the situation in external trade affairs which fall under the Community pillar. In external trade affairs, the European Parliament is increasingly taken seriously, linked, of course, to its stronger role provided in the treaties in this field. Although the low legitimacy of the European Parliament in the dominant CFSP discourse could be seen as a simple reflection of the role accorded to the different institutional actors in the treaties with regard to foreign affairs, it can be interpreted in an alternative way from a discourse perspective: treaty changes in the field of EU foreign policy have to a large extent been codifications of already developed policy practices and arguably take place within the framework of the dominant discourse on the CFSP.

\section{Concluding remarks}

In this chapter, I began with a brief introduction to discourse analysis. I then presented three central dimensions of discourse analysis, along the lines of Milliken (1999): representation, policy practice, and play of practice and attempted to show how these three dimensions can serve to shed light on what I see as central aspects of EU foreign policy (actor status, actor attributes and values, decision-making procedures). The focus was on how these issues can be approached from a discourse perspective. I described work which has been carried out in this field, partly from a discourse perspective, partly from perspectives that lend themselves to interpretation in terms of the discourse perspective.

My conclusion is that there is wide scope for drawing on discourse analysis for analysing European foreign policy. But the conclusion is also that little research has been done which has explicitly and systematically drawn on a discourse analytical framework. From the perspective outlined here, the recommendation is for research which more directly uses a discourse analytical theory and method. In this respect, it should be stressed that there are many different approaches to social constructivist discourse analysis. Which one is chosen has 
important consequences for the way the analysis is conducted, since some approaches lend themselves more easily to being combined with other kinds of theoretical framework than others. The post-structuralist discourse analytical approach of Laclau and Mouffe, for example, cannot easily be combined with other non-discourse approaches since the point is that all societal phenomena are discursive. The critical discourse analysis of Norman Fairclough, on the other hand, can more easily be used in combination with other theoretical approaches since it operates with societal phenomena other than discursive phenomena (Jørgensen and Phillips 2002).

\section{Notes}

1 It is, however, rarely clear what the precise criteria for this demarcation are. In some respects, social constructivist approaches might for example draw on a rather rationalist/ modernist epistemology, while in other respects dealing with the same foci or ontology as post-structuralists, such as identity, language and discourse. It seems more appropriate to say that there are many social constructivist approaches which in some respects might be more or less close to rationalists, while in others they are more or less close to the assumptions and foci of oststructuralists/deconstructivists (for a distinction between different strands see Ruggie 1998b: 880-2. For the distinction between constructivists and deconstructivists see Wrver 1997. See also Larsen 1997a: 244).

2 For this point in sociology see Bertilsson and Järvinen (1998: 10). For philosophy see for example Collin (1997), who does not distinguish between linguistic and non-linguistic approaches to social construction.

3 For a description and a comparison between these two approaches see Jørgensen and Phillips (2002).

4 Wendt relies heavily on symbolic interactionism (1992; 1999: 1, 170-1, 336).

5 One weakness in Milliken's categorisation is that she seems to suggest that discourse analysis is basically one unitary school.

6 For the issue of whether national or common understandings shape national policy see Wendt (1992: 423).

7 This builds on empirical analysis of a corpus of EU documents from the 1990s. For a list of these see Larsen (2000a: 240).

8 For an attempt to distinguish analytically in an empirical study see Larsen (1997b).

9 The question is whether there are social practices other than discursive practices. This is where macro approaches to discourse analysis vary, CDA assuming that there are social practices other than discursive practices, the theory of Laclau and Mouffe assuming that there are not.

10 For an analysis along these lines concerning general EU policy, see for example Larsen (1997b) and Wæver (1990).

11 Most notably I do not go into the issue of genealogy in relation to European foreign policy. Neither do I go into deconstruction, where very little work has been done (see, however, Wæver 1994: 248).

12 Not least because Duchêne's argument for why the EU is a civilian power is, to a large extent, based on the circumstances of the early 1970s (see for instance Duchêne 1972: 38).

13 See also the Presidency's conclusions from the European councils in Helsinki (1999) and Feira (June 2000) (European Council, Presidency Conclusions 1999 and 2000).

14 See for example TOA Article 11. 
15 Recognition by other international actors as a necessary component of actorness from a discourse perspective is not a given. Neumann has argued that there is a difference between the role of 'the other' within constructivism and post-structuralism. The 'other' in constructivism contributes to constituting the ego by recognising ego. In post-structuralism the 'other' is part of ego's self-definition through a kind of mirror function, what ego is not. The recognition aspect is not stressed (Neumann 1998: ch. 8). The position in this chapter, however, is that the recognition aspect can be contained within a discourse perspective.

16 Neumann (1998: ch. 2) also describes how Turkey has previously had this defining 'othering' function for Europe, particularly when it was politically strong.

17 The focus on liberal values is of course a common Western focus, in particular after the Cold War.

18 See K. Smith (1998b: 267). 